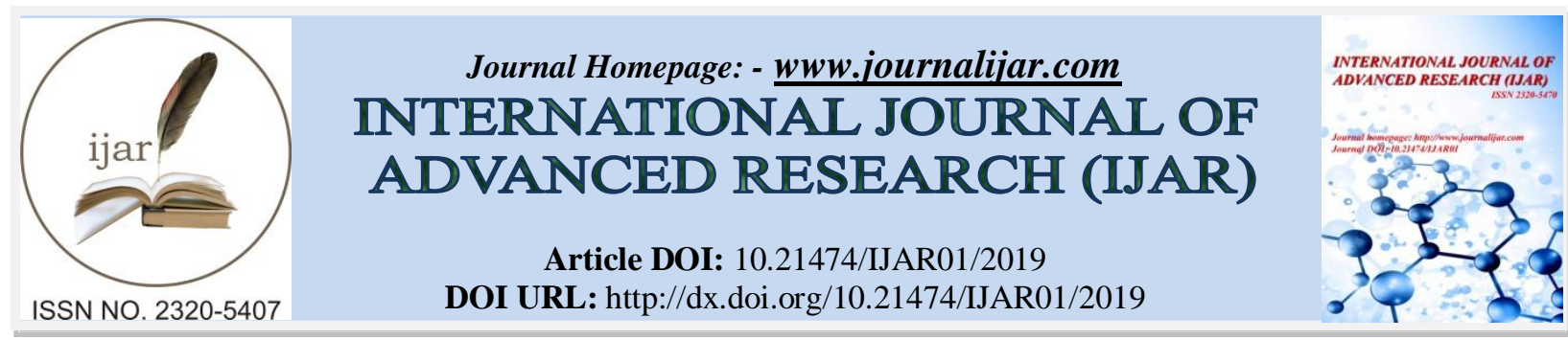

RESEARCH ARTICLE

\title{
POPULATION DYNAMICS AND MANAGEMENT OF SUGARCANE WOOLLY APHIDS, CERATOVACUNA LANIGERA (ZEHNTNER) (HEMIPTERA : APHIDIDAE) WITH NEW MOLECULES OF INSECTICIDES.
}

Mangesh A. Mane, Pandurang B. Mohite and Sarjarao A. Patil.

Department of Entomology College of Agriculture, Kolhapur (M.S.)

\section{Manuscript Info}

Manuscript History

Received: 25 September2016

Final Accepted: 9 October 2016

Published: October 2016

Key words:-

Sugarcane Woolly Aphids, fertera, fipronil, cartap Hydrochloride, fipronil $40 \%+$ imidacloprid

\section{Abstract}

The incidence of Sugarcane Woolly Aphids was found sever in the months of September, October and November, 2011, but later on with increase in maximum temperature and decrease in relative humidity in the month of December, the population of woolly aphids declined Among the insecticides tested the drenching with fipronil $40 \%+$ Imidacloprid 40\% $80 \mathrm{WG} @ 250 \mathrm{~g}$ a.i./ha proved to be most effective and superior over the rest of the treatment and recorded highest 78.49 per cent mortality. The treatment with fertera $0.4 \mathrm{G} @ 30 \mathrm{~g}$ a.i./ha stood second in order of effectiveness recording 74.69 per cent mortality however, it was at par with fipronil $0.3 \mathrm{G} @ 7.5 \mathrm{~g}$ a.i/ha which recorded 74.35 per cent mortality. The next best treatment cartap hydrochloride 4G @ 750 g a.i./ha recording 71.02 per cent mortality. This was followed by the treatment with chloropyriphos 10 $\mathrm{G}$, carbofuran $3 \mathrm{G}$ and phorate $10 \mathrm{G}$ in where $68.90,67.59$ and 63.59 per cent mortality is noticed, respectively.

Copy Right, IJAR, 2016,. All rights reserved.

\section{Introduction:-}

Sugarcane supports two important rural and cottage industries, viz. Gur (Jaggary) and Khandsari industries. By product like molasses is the main raw material for alcohol and alcohol based industries. Sugarcane bagasse is the chief source of power in sugarcane mills. Sugarcane green tops are used as cattle feed. By products of sugar industry such as molasses, bagasse and press mud play an important role in the national economy. About 125 species of insects are known to infest the sugarcane as major pests in various parts of the world (Patil et al., 2004). In India, nearly 228 insect and non-insect pests are attacking the crop (David and Nandagopal, 1986). An economical loss in sugarcane has been estimated to the extent of 20 per cent in cane yield and 15 per cent in sugar recovery due to the ravages of the insect pests (Avasthy, 1977).

In sugarcane, due to monoculture, availability of food throughout the year, staggered planting, soft and high sugar varieties and favourable climatic conditions; some of the minor pests like whitefly, scale insects and sugarcane woolly aphid are attaining the status of major pests causing notable losses. Among them Sugarcane Woolly Aphid (SWA), Ceratovacuna lanigera (Zehntner) (Homoptera: Aphididae) has been the latest threat to sugarcane crop as well as sugar industry in the country (Patil et al., 2004). 


\section{Material and Methods:-}

Observations were recorded from January, 2011 when the crop was planted. Twenty sugarcane clumps were selected and tagged at random. Five leaves per clump with high SWA population were selected. Observations were recorded at weekly interval for one year starting from January, 2011 to December, 2011. Five canes were selected randomly by considering two leaves per cane on the number of aphids present in $2.5 \times 2.5 \mathrm{sq}$. cm window at 3 locations on each leaves at three places (i.e. bottom, middle and top). The total number of natural enemies were counted along the entire surface of the same leaf on which the aphids were counted.

Efficacy of insecticides were tested in spray and granular formulation for management of this pest. Application of insecticides was undertaken after sufficient population buildup was observed. The crop was sprayed twice using knapsack sprayer with different treatments at an interval of 30 days. Observations were recorded on five randomly selected cane by considering two leaves per cane on the number of aphids present in $2.5 \times 2.5 \mathrm{sq}$. cm window at 3 locations on each leaf, 1 day before and 5, 10 and 15 days after applications as suggested by Patil et al. (2005). The data on per cent mortality of pest was analyzed statistically.

\section{Results and Discussion:-}

The sugarcane woolly aphid was noticed in $27^{\text {th }}$ meteorological week $\left(1^{\text {st }}\right.$ week of July, 2011) when the crop was 7 months old. The pest activity was increased in subsequent months. The maximum activity of aphid was recorded during $45^{\text {th }}$ meteorological week $\left(1^{\text {st }}\right.$ week of November, 2011) when average number was 57.71 aphids $/ 2.5 \mathrm{~cm}^{2}$ /leaf. The pest was found sever in the months of September, October and November, 2011, but later on with increase in maximum temperature and decrease in relative humidity in the month of December, the population of woolly aphids declined (Table 1$)$. Maximum temperature $\left(-0.338^{*}\right)$, minimum temperature $\left(-0.449^{* *}\right)$, evening humidity $\left(-0.385^{* *}\right)$ and rainfall $\left(-0.349^{* *}\right)$ were negatively correlated with SWA population but highly significant except maximum temperature. Morning humidity $(0.320)$ was positively correlated with SWA population.

Table 1:- Correlation of SWA population with weather parameters.

\begin{tabular}{|l|c|}
\hline Weather parameter & Correlation coefficient ('r' value) \\
\hline Maximum Temperature & $-0.338^{*}$ \\
\hline Minimum Temperature & $-0.449^{* *}$ \\
\hline Morning Humidity & 0.320 \\
\hline Evening Humidity & $-0.385^{* *}$ \\
\hline Rainfall & $-0.349^{* *}$ \\
\hline
\end{tabular}

* Significant at 5 per cent level. ** Significant at 1 per cent level.

The results indicated that, the natural enemies viz., M. igorotus, D. aphidivora and E. confracter were highly significant and were positively correlated with pest population. The results are in conformity with Patil (2003) who reporteded that the average population of SWA was 5.3 per $5 \mathrm{~cm}^{2}$ leaf area during the month of July with corresponding leaf infestation being 42.11 per cent. Ghorpade et al., (2006) reported that the activity of SWA was started in the month of September and reached peak in the month of December.

Thakur (2007) reported that the maximum activity of apterous forms of $C$. lanigera was observed from mid October, 2003 to end of January, 2004 and population disappeared in May, 2004 and the late forms were appeared in first fortnight of July, 2003 and remained active till March, 2004 but the activity of predator, D. aphidivora was maximum (2.67/leaf/plant) in second fortnight of February, 2004.

The data presenting on per cent mortality of pest under field condition are given in Table 2 . The result reveled that all the insecticide treatment recorded significantly more per cent mortality compared to untreated control up to 15 DAT.

Table 2:- Relationship between natural enemies and activity of SWA.

\begin{tabular}{|c|c|}
\hline Natural enemies & Correlation coefficient \\
\hline M. igorotus & $0.924^{* *}$ \\
\hline D. aphidivora & $0.773^{* *}$ \\
\hline E. confester & $0.891^{* *}$ \\
\hline
\end{tabular}

** Significant at 1 per cent level. 
At 5 DAT the per cent mortality observed in different granular insecticides treatment where 76.75 to 62.42 per cent was recorded. Among the insecticide tested the drenching with Fipronil 40\% + Imidacloprid 40\%80 WG @ 250 g a.i. /ha proved to be most effective and superior over all the rest of the treatment and recorded 76.75 per cent mortality. The treatment with fertera $0.4 \mathrm{G} @ 30 \mathrm{~g}$ a.i./ha stood second in order of efficacy recording 74.23 per cent mortality. The treatment with fipronil $0.3 \mathrm{G} @ 7.5 \mathrm{~g}$ a.i/ha recorded 74.12 per cent mortality, cartap hydrochloride $4 \mathrm{G} @ 750 \mathrm{~g}$ a.i./ha recorded 71.14 per cent mortality and chlorpyriphos $10 \mathrm{G}$, carbofuran $3 \mathrm{G}$ and phorate $10 \mathrm{G}$ were next in order of efficacy.

At 10 DAT the per cent mortality observed in different granular insecticides treatment where 79.13 to 63.74 per cent was recorded. Among the insecticide tested the drenching with Fipronil 40\% + Imidacloprid 40\%80 WG @ 250 g a.i. /ha proved to be most effective and superior over all the rest of the treatment and recorded 79.13 per cent mortality. The treatment with fertera $0.4 \mathrm{G} @ 30 \mathrm{~g}$ a.i./ha stood second in order of efficacy recording 74.85 per cent mortality. The treatment with fipronil $0.3 \mathrm{G} @ 7.5 \mathrm{~g}$ a.i/ha recorded 74.61 per cent mortality, cartap hydrochloride 4G @ 750 g a.i./ha recorded 70.92 per cent mortality and chloropyriphos $10 \mathrm{G}$, carbofuran $3 \mathrm{G}$ and phorate $10 \mathrm{G}$ were next in order of efficacy.

At 15 DAT the per cent mortality observed in different granular insecticides treatment where 79.61 to 64.61 per cent was recorded. Among the insecticide tested the drenching with Fipronil 40\% + Imidacloprid 40\% 80 WG @ 250 g a.i./ha proved to be most effective and superior over all the rest of the treatment and recorded 79.61 per cent mortality. The treatment with fertera $0.4 \mathrm{G} @ 30 \mathrm{~g}$ a.i./ha stood second in order of efficacy recorded 75.01 per cent mortality. The treatment with fipronil $0.3 \mathrm{G} @ 7.5 \mathrm{~g}$ a.i/ha recorded 74.32 per cent mortality, cartap hydrochloride 4G @ $750 \mathrm{~g}$ a.i./ha recorded 71.01 per cent mortality and chlorpyriphos $10 \mathrm{G}$, carbofuran $3 \mathrm{G}$ and phorate $10 \mathrm{G}$ were next in order of efficacy.

Overall performance of various granular insecticidal treatments (Table 1) based on the mean indicated that treatment with Fipronil $40 \%$ + Imidacloprid $40 \% 80 \mathrm{WG}$ was found the most effective and significantly superior over all other treatments after 5, 10 and 15 days after treatment the per cent mortality observed in different granular insecticides treatment was between 78.49 to 63.59 per cent as against 0.00 per cent in untreated control. Among the insecticide tested the drenching with Fipronil 40\% + Imidacloprid 40\% $80 \mathrm{WG} @ 250 \mathrm{~g}$ a.i./ha proved to be most effective and superior over all the rest of the treatment consistently and recorded highest 78.49 per cent mortality. The treatment with fertera 0.4 $\mathrm{G} @ 30 \mathrm{~g}$ a.i./ha stood second in order of efficacy and recorded 74.69 per cent mortality. Fipronil $0.3 \mathrm{G} @ 7.5 \mathrm{~g}$ a.i/ha recorded 74.35 per cent mortality, cartap hydrochloride $4 \mathrm{G} @ 750 \mathrm{~g}$ a.i./ha recorded 71.02 per cent mortality. The treatment with chloropyriphos $10 \mathrm{G}$, carbofuran $3 \mathrm{G}$ and phorate $10 \mathrm{G}$ in which $68.90,67.59$ and 63.59 per cent mortality recorded, respectively and they were next in order of efficacy.

Patil et al., (2004) and Shankar and Shitole (2004) reported that soil application of phorate 10G @ 2.5 and $3.0 \mathrm{~kg}$ a.i./ha reduced the aphid population to the tune of 90 per cent.

Table 3:- Efficacy of granular insecticides against sugarcane woolly aphid, C. lanigera (Zehntner).

\begin{tabular}{|c|c|c|c|c|c|c|}
\hline \multirow{2}{*}{\multicolumn{2}{|c|}{ Treatment }} & \multirow{3}{*}{$\begin{array}{l}\text { No. of SWA/2.5 } \mathrm{cm}^{2} \mathbf{1} \\
\text { DBA } \\
40.12\end{array}$} & \multicolumn{3}{|c|}{$\begin{array}{l}\text { Per cent mortality of sugarcane woolly } \\
\text { aphids }\end{array}$} & \multirow[t]{2}{*}{ Mean } \\
\hline & & & 05 DAA & 10 DAA & 15 DAA & \\
\hline $\mathrm{T} 1$ & Carbofuran $3 \mathrm{G}$ & & $\begin{array}{c}67.71 * \\
(55.37)^{* *}\end{array}$ & $\begin{array}{c}67.44 \\
(55.20) \\
\end{array}$ & $\begin{array}{c}67.62 \\
(55.28)\end{array}$ & $\begin{array}{c}67.59 \\
(55.28)\end{array}$ \\
\hline $\mathrm{T} 2$ & Fertera $0.4 \mathrm{G}$ & 41.32 & $\begin{array}{c}74.23 \\
(59.50) \\
\end{array}$ & $\begin{array}{c}74.85 \\
(59.87) \\
\end{array}$ & $\begin{array}{c}75.01 \\
(60.00) \\
\end{array}$ & $\begin{array}{c}74.69 \\
(59.79) \\
\end{array}$ \\
\hline T3 & $\begin{array}{l}\text { Fipronil } 40 \% \text { + Imidacloprid } 40 \% \\
80 \mathrm{WG}\end{array}$ & 39.22 & $\begin{array}{c}76.75 \\
(61.16) \\
\end{array}$ & $\begin{array}{l}79.13 \\
(62.76)\end{array}$ & $\begin{array}{c}79.61 \\
(63.15)\end{array}$ & $\begin{array}{r}78.49 \\
(62.35)\end{array}$ \\
\hline $\mathrm{T} 4$ & Fipronil $0.3 \mathrm{G}$ & 37.13 & $\begin{array}{c}74.12 \\
(59.43) \\
\end{array}$ & $\begin{array}{c}74.61 \\
(59.74) \\
\end{array}$ & $\begin{array}{c}74.32 \\
(59.54) \\
\end{array}$ & $\begin{array}{c}74.35 \\
(59.57) \\
\end{array}$ \\
\hline T5 & Cartap 4 G & 38.40 & $\begin{array}{c}71.14 \\
(57.46) \\
\end{array}$ & $\begin{array}{c}70.92 \\
(57.35) \\
\end{array}$ & $\begin{array}{c}71.01 \\
(57.42) \\
\end{array}$ & $\begin{array}{c}71.02 \\
(57.41) \\
\end{array}$ \\
\hline T6 & Phorate $10 \mathrm{G}$ & 40.23 & $\begin{array}{c}62.42 \\
(52.21) \\
\end{array}$ & $\begin{array}{c}63.74 \\
(52.93) \\
\end{array}$ & $\begin{array}{c}64.61 \\
(53.47) \\
\end{array}$ & $\begin{array}{r}63.59 \\
(52.87) \\
\end{array}$ \\
\hline $\mathrm{T} 7$ & Chlorpyriphos $10 \mathrm{G}$ & 41.71 & $\begin{array}{c}68.75 \\
(56.00) \\
\end{array}$ & $\begin{array}{c}68.94 \\
(56.13) \\
\end{array}$ & $\begin{array}{c}69.03 \\
(56.17) \\
\end{array}$ & $\begin{array}{r}68.90 \\
(56.10) \\
\end{array}$ \\
\hline T8 & Untreated control & 44.52 & $\begin{array}{c}00 \\
(00.00) \\
\end{array}$ & $\begin{array}{c}00 \\
(00.00)\end{array}$ & $\begin{array}{c}00 \\
(00.00) \\
\end{array}$ & $\begin{array}{c}00 \\
(00.00) \\
\end{array}$ \\
\hline & S.E. & - & 0.17 & 0.16 & 0.17 & 0.16 \\
\hline & C.D.@ 5\% & NS & 0.51 & 0.47 & 0.52 & 0.50 \\
\hline
\end{tabular}

DBA- Days before application. DAA - Days after application. * Mean of three replications. ** Figures in parenthesis are arcsine transformed values. 


\section{References:-}

1. Avasthy, P. N., 1977. Integrated Control of Sugarcane Pests and Diseases, Sug. News, 9:72-74.

2. David, H and V. Nanddagopal, 1986. Pests of sugarcane distribution, symptomatology of attack and identification.

3. Sugarcane Entomology in India. Sugarcane Breeding Institute (ICAR), Publication, Coimbatore, India. pp. $1-29$.

4. Ghorpade, S. A., D. S. Pokharkar, P. Sinha and R. J. Rabindra, 2006. Biological suppression of sugarcane woolly aphid, Ceratovacuna lanigera Zehntner in Maharashtra. Proceedings of National Symposium on Biological control of sucking pests in India, PDBC, Bangalore, May 26-27, pp.39.

5. Patil, A. S., 2002. Pandhrya, lokari mavyapasun us wachavinyasathi Rathangiri stani, sheti puravani, 26 Sept 2002.

6. Patil, R. K., G. K. Ramegowda, V. Rachappa, S. Lingappa and P. S.

7. Tippannavar, 2003. Records of woolly aphid, Ceratovacuna lanigera Zehntner (Homoptera: Pemphigidae) on sugarcane in North Karnataka, Ins Envt, 9: 57-59.

8. Patil, A. S., V. D. Shinde, S. B. Mager, R. G. Yadav and Y. S. Nerkar, 2004. Sugarcane woolly aphid (Ceratovacuna lanigera) its history and control measures. Proceedings of Sugarcane Technologists Association in India, pp.133-155.

9. Patil, S. B., P. S. Tippannavar, S. A. Patil, N. Balsundaram, S. $\quad$ Lingappa, M. V. C. Gowda, B. M. Khadi, P. M. Salimath, N. Y.

10. Nayakar, B. N. Bhat and N. S. Kambar, 2005. Identification of sugarcane clones resistant to the sugarcane woolly aphid,

11. (Ceratovacuna lanigera Zehntner). Current Science, 88 :284-288.

12. Shankar, G. and D. M. Shitole, 2004. Management of Sugarcane woolly aphid, Ceratovacuna lanigera Zehntner (Homoptera : $\quad$ Aphididae), Pestology, 28: 25-26.

13. Thakur, S. G., 2007. Studies on Biology and Management of sugarcane woolly aphid, Ceratovacuna lanigera Zehntner (Homoptera: Aphididae), Ph.D. Thesis, Mahatma Phule Krishi Viyapeeth, Rahuri, India. 